\title{
UPAYA MENINGKATKAN HASIL BELAJAR IPS SISWA KELAS 7.2 SMPN 3 MALANG MELALUI MODEL STUDENT TEAM ACHIEVEMENT DIVISION (STAD) PADA MATERI PENDUDUK INDONESIA DAN PEMANFAATAN SUMBER DAYA ALAM
}

\author{
Suriyanto \\ Universitas Kanjuruhan Malang \\ Email: suriyanto321@gmail.com
}

\begin{abstract}
Abstrak
Tujuan penelitian ini adalah untuk meningkatkan hasil belajar IPS Siswa kelas 7.2 semester 2 SMPN 3 Malang pada materi Penduduk Indonesia dan Pemanfaatan Sumber Daya Alam melalui penerapan model pembelajaran kooperatif tipe Student Teams Achievement Division. Hasil penelitian menunjukkan bahwa ada peningkatan hasil belajar sebelum dan sesudah menggunakan model pembelajaran tipe STAD dengan ditunjukan data sebagai berikut. Ketuntasan belajar sebelum pra tindakan yaitu sebesar $60 \%$ kemudian siklus I meningkat 63,33\%, dan siklus II meningkat menjadi $80 \%$.
\end{abstract}

Kata Kunci: Student Teams Achievement Division (STAD), hasil belajar

\section{PENDAHULUAN}

Hasil observasi peneliti dikelas 7.2 Sekolah Menengah Pertama Negeri 3 Malang pada tanggal 12 Oktober - 30 November 2013 diketahui bahwa ada beberapa siswa yang hasil belajarnya di bawah Kriteria Ketuntasan Minimal. Berdasarkan data yang peneliti dapatkan bahwa dari 30 siswa sebanyak 18 orang siswa atau $60 \%$ yang mencapai target $\geq 80$ sedangkan siswa yang dibawah $\leq$ 80 sebanyak 12 orang atau $40 \%$.

Selain itu hasil wawancara Peneliti pada tanggal 25 Oktober 2013 di SMP N 3 Malang kelas 7.2, sembilan dari sepuluh siswa menyatakan Ilmu Pengetahuan Sosial merupakan pelajaran yang membosankan. Pernyataan siswa ini bukan tanpa alasan dari berbagai pernyataan siswa tersebut, peneliti menyimpulkan bahwa alasan siswa mengatakan pelajaran Ilmu Pengetahuan Sosial membosankan karena disebabkan karena pada proses belajar mengajar terlalu banyak konsep yang harus dihafalkan selain itu juga dalam proses belajar mengajar model yang diterapkan hanya fokus pada satu model saja sehingga menimbulkan rasa bosan.

Data di atas menunjukan perlu adanya perbaikan hasil belajar agar kedepanya hasil pelajaran Siswa lebih baik lagi. Cara yang perlu dilakukan untuk mengatasi permasalahan di atas adalah perlu dilakukan penelitian tindakan kelas. Menyikapi materi yang akan diajarkan kedepanya terkait Penduduk Indonesia dan Pemanfaatanya Sumber Daya Alam sub tema komposisi penduduk. Dalam materi ini memiliki karakteristik yang menginginkan siswa yaitu (1) Dapat menjelaskan komposisi penduduk berdasarkan pendidikan, (2) Dapat menjelaskan komposisi penduduk berdasarkan agama (3) Dapat menjelaskan komposisi penduduk 
berdasarkan umur (4) Dapat menjelaskan komposisi penduduk berdasarkan jenis kelamin (5) Dapat menjelaskan komposisi berdasarkan bidang usaha (6) Dapat menjelaskan komposisi penduduk berdasarkan wilayah geografis desa dan kota. Melihat karateristik materi yang harus dikuasai oleh siswa begitu kompleks sehingga penanganan yang tepat yaitu dengan menerapkan model pembelajaran kooperatif tipe Studen Teams Achiement Division (STAD).

Model pembelajaran Kooperatif tipe Student Teams Achievement Division (STAD) diyakini tepat ditepat diterapkan pada materi ini karena selain membentuk sikap atau kepribadian, juga menekankan siswa untuk memahami materi secara mandiri dengan mencari dengan berbgai sumber informasi selain itu juga model pembelajaran tipe ini tepat dalam meingkatkan hasil belajar siswa karena siswa akan lebih paham dalam memahami materi ketika dilkukan proses diskusi dan tentunya hal tersebut dapat meningkatkan hasil belajar siswa. Pernyataan ini juga diperkuat oleh para ahli yang menyatakan pemebelajaran bisa efektif apabila siswa secara aktif dilibatkan dalam pengorganisasian dan penemuan informasi.

Berdasarkan Latar belakang diatas maka tujuaan penelitian ini adalah untuk meningkatkan hasil belajar Ilmu Pengetahuan Sosial Siswa kelas 7.2 semester 2 SMPN 3 Malang pada materi Penduduk Indonesia dan Pemanfaatan Sumber Daya Alam melalui penerapan pembelajaran model Student teams Achievement Division (STAD).

Hasil penelitian ini diharapkan dapat memberikan manfaat bagi:
1. Guru Ilmu Pengetahuan Sosial sebagai bahan informasi dan motivasi tentang pengetahuan mereka terhadap karakteristik yang dimilikinya dan guru - guru yang lainnya dalam pembelajaran Ilmu Pengetahuan Sosial dan pengaruhnya terhadap hasil belajar siswa secara umum.

2. Lembaga Pendidikan sebagai motivasi agar senantiasa melakukan upaya peningkatan kualitas guru dan sebagai bahan informasi untuk selalu memperhatikan usaha pengembangan sistem pembelajaran Ilmu Pengetahuan Sosial di tingkat SMP dan diharapkan untuk pihak penentu kebijakan bisa dijadikan sebagai rujukan untuk pengembangan pendidikan dalam bidang Ilmu Pengetahuan Sosial

3. Bagi Kampus Universitas Kanjuruhan Malang penelitian ini bermanfaat sebagai bahan rujukan untuk pengembangan kualitas mahasiswa dalam bidang pendidikan, mengingat pentingnya penguasaan kompetensi pada bidangnya.

4. Peneliti atau Mahasiswa yaitu sebagai bahan informasi dan pengetahuan tentang karakteristik guru Ilmu Pengetahuan Sosial terhadap hasil belajar siswa. Serta dapat dijadikan bekal untuk terjun di lingkungan sekolah nantinya. Dan penelitian ini dapat bermanfaat untuk penulis sebagai pengembangan pengetahuan penulis sendiri di lapangan sesuai dengan jurusan yang penulis tekuni.

\section{METODE PENELITIAN}

Sesuai dengan jenis penelitian yang dipilih, yaitu penelitian tindakan kelas maka penelitian ini bersifat kolaboatif. Penelitian Tindakan kelasa bertujuaan 
untuk memperbaiki suatu keadaan pembelajaran dikelas dengan dengan melakukan tindakan - tindakan agar terjadi perubahan menuju kearah yang lebih baik. Peneletian tindakan kelas akan dilaksanakan dalam 2 siklus tindakan sesuai dengan beberapa tahapan ditas, setiap siklus terdiri atas dua kali pertemuan selama 2 jam pelajaran. Setiap siklus tindakan yang dilaksanakan terdiri atas empat komponen yang dapat digambarkan dalam bentuk spiral sebagai berikut.

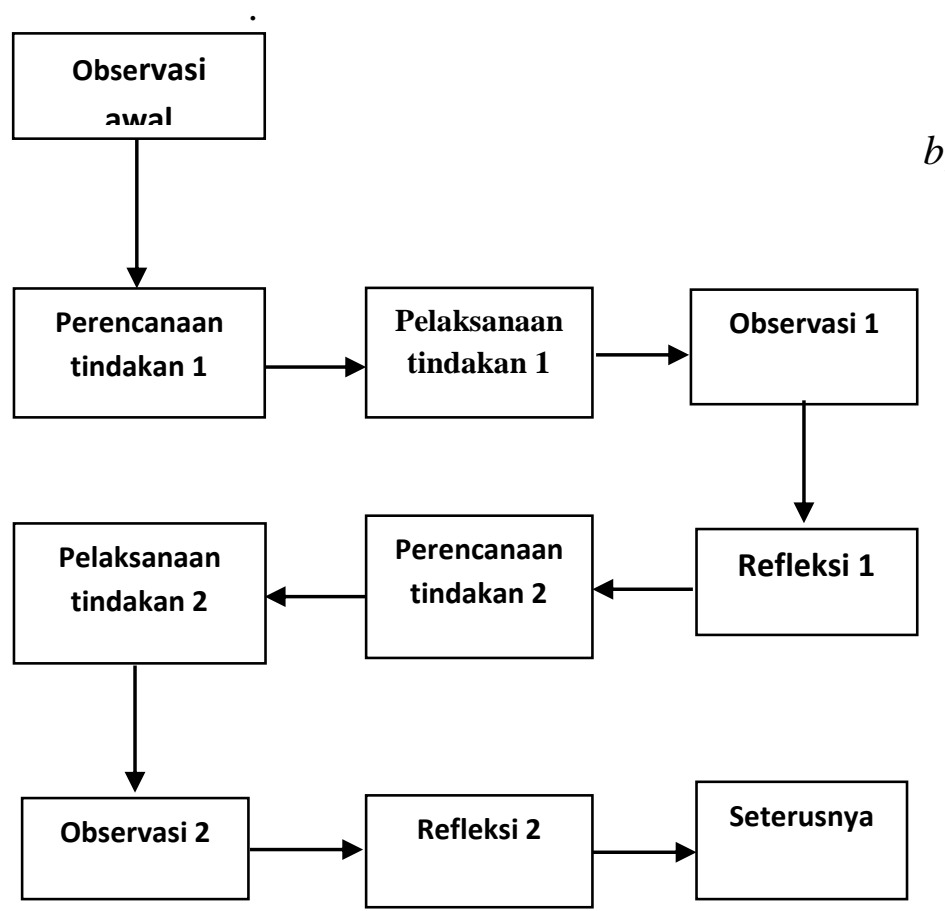

Gambar 1. Bagan Penelitian Tindakan Kelas (Adopsi dari Tim Pelatihan Proyek PGSM 1992:2)

a) Subyek penelitian adalah siswa siswi kelas 7.2 mata pelajaran IPS di SMP Negeri 3 Malang pada pokok bahasan materi Penduduk Indonesia dan Pemanfaatan Sumber Daya Alam.

b) Objek Penelitian adalah hasil belajar siwa - siswi kelas 7.2 SMP Negeri 3 Malang pada pokok materi Penduduk Indonesia dan Pemanfaatan Sumber Daya Alam.

\section{Prosedur Penelitian}

Dalam prosedur penelitian ini meliputi ada beberapa tahapan - tahapan yang akan dilaksanakan yaitu :

a) Kegiatan Pra-Penelitian

Kegiatan pra - penelitian berupa kegiatan observasi yang dilakukan sebelum penelitian, meliputi observasi tentang kondisi siswa di kelas pada saat pembelajaran berlangsung, ketersediaan sarana dan prasarana dan kondisi siswa serta mengamati permasalahan yang sering terjadi dalam proses pembelajaran dengan melakukan wawancara dengan siswa.

b) Pelaksanaan Penelitian

Penelitian ini dilaksanakan melalui 4 tahap, yaitu,

1. Planing (Perencanaan)

Rancangan/Perencana yaitu kegiatan awal sebelum mengadakan penelitian peneliti menyusun rumusan masalah, tujuan dan membuat rencana tindakan, termasuk di dalamnya instrumen penelitian dan perangkat pembelajaran.

2. Action (Tindakan)

Pada tahap tindakan yang dimaksud guru sebagai peneliti yang dilakukan secara sadar dan terkendali dan merupakan variasi praktik yang cermat dan bijaksana. Dalam konteks ini, tindakan itu digunakan sebagai kebijakan bagi guru untuk pengembangan tindakan tindakan berikutnya, yaitu tindakan yang dilakukan guru yang disertai kemauan kuat untuk memperbaiki proses pembelajarannya.

\section{Observasi (Pengamatan)}


Observasi atau pengamatan dilakukan oleh guru sebagai peneliti memperoleh gambaran secara cermat tentang tindakan yang sedang dilakukan dan kemudian mendokumentasikan pengaruh atau dampak dari tindakan tersebut. Pada dasarnya pengamatan berorientasi ke masa yang akan datang, memberikan dasar bagi kegiatan refleksi pada saat sekarang, lebih - lebih lagi ketika putaran atau siklus tindakan itu sedang berjalan.

4. Reflection (Refleksi)

Peneliti mencoba mengingat, merenungkan, mencermati dan menganalisis kembali suatu kegiatan atau tindakan yang telah dilakukan.

\section{Instrumen Penelitian Dan Teknik Pengumpulan Data}

a. Instrumen Penelitian

1) Lembar Kerja Siswa

Bertujuan untuk menguji kemapuan siswa berbentuk tugas baik tugas individu maupun tugas kelompok, sebagai tolak ukur apakah model yang diterapakana dapat mengupayakan peningkatan hasil belajar siswa

2) Lembar Observasi

Observasi dilakukan pada saat peneliti melakukan tindakan penelitian, data diperoleh dengan menggunakan lembar observasi. Lembar observasi pada penelitian ini digunakan untuk menilai siswa pada saat proses pembelajaran.

b. Teknik Pengumpul Data

1 Dokumentasi

Dalam penelitian ini dokumentasi yang digunakan berupa gambar atau foto-foto kegiatatn siswa dan kegiatan guru selama proses kegiatan belajar berlangsung. Hasil dari dokumentasi tersebut, digunakan untuk melengkapi data dari hasil penelitian tindakan kelas yang dilakukan.

2. Catatan Lapangan

Lapangan digunakan untuk mencatat hal-hal yang terkait dengan penelitian tetapi belum tercantum pada lembar observasi seperti: nama-nama siswa yang tidak masuk, situasi saat kegiatan belajar berlangsung, nama siswa yang membuat gaduh atau ramai dan nama siswa yang selalu pasif dan sebagainya.

\section{Analisis Data}

Pada penelitian ini data yang diperoleh adalah data kuantitatif yang selanjutnya akan dianalisis secara deskriptif. Data hasil tes digunakan untuk mengetahui ketuntasan hasil belajar siswa. Ketuntasan belajar siswa untuk mata pelajaran Ilmu Pengetahuan Sosial di SMPN 3 Malang sebesar 80\%. Apabila siswa telah mencapai nilai diatas 80 sebanyak $80 \%$ dari jumlah seluruh kelas atau secara individu siswa mendapatkan nilai diatas 80 maka pembelajaran di kelas tersebut dikatakan tuntas.

\section{HASIL DAN PEMBAHASAN}

Pada saat sebelum tindakan rata-rata hasil belajar yaitu sebesar 74.4 atau $60 \%$ dan pada siklus 1 rata-rata hasil belajar siswa sebesar kemudian meningkat lagi yaitu sebesar 78.00 dengan ketuntasannya $63 \%$ dan kemudian meningkat lagi pada siklus 2 yaitu sebesar 85.33 atau dengan nilai ketuntasan sebesar $80 \%$. Siswa yang sudah tuntas sebelum pra tindakan sebanyak 18 , kemudian pada tindakan 
siklus I menjadi 19 dan pada tindakan siklus 2 siswa yang tuntas sebanyak 24.Peningkatan hasil belajar dari data awal sebelum penelitian, siklus I dan siklus 2. Hasil belajar siswa disajikan pada grafik dibawah ini.

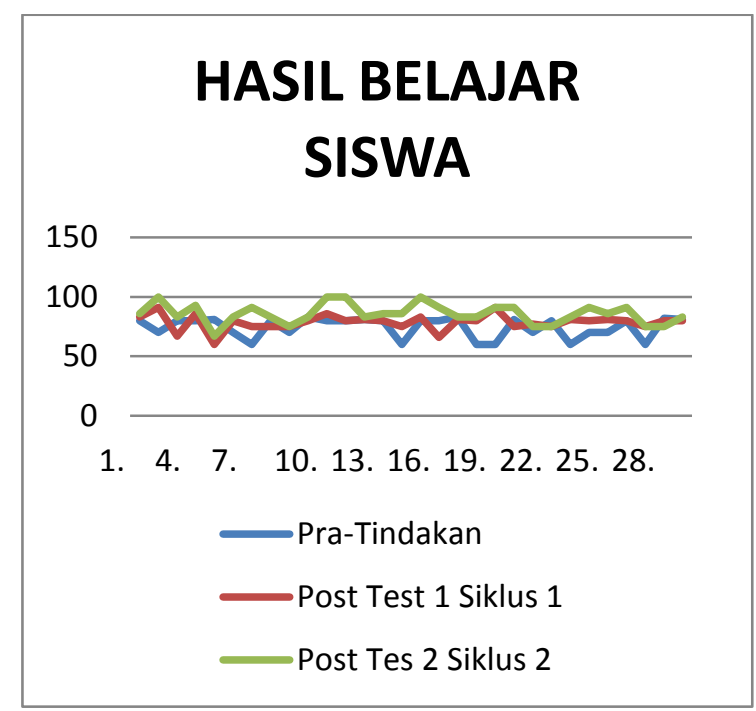

Gambar 2. Diagram Garis Hasil Belajar Siswa Siklus 1 dan 2

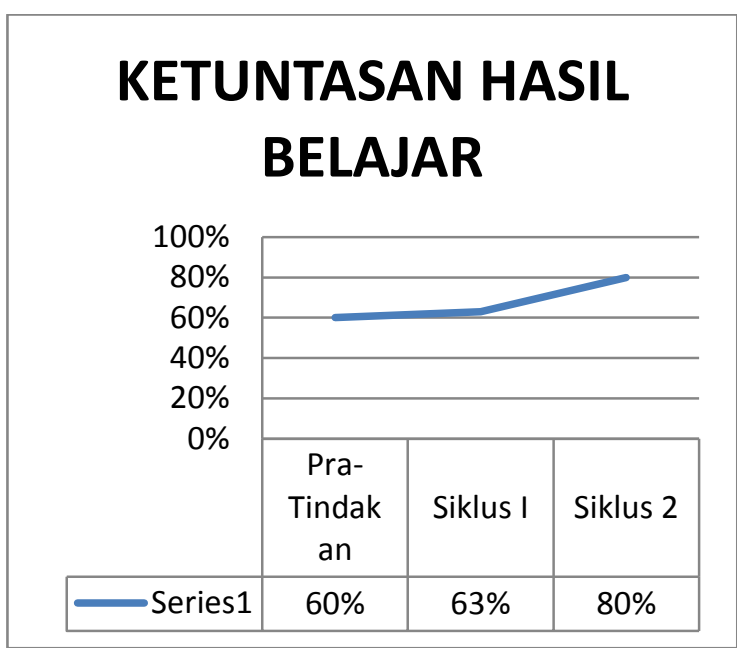

Gambar 3. Diagram Garis Ketuntasan Belajar Siklus 1 dan 2

Berdasarkan penelitian yang dilakukan dalam penerapan pembelajaran STAD didapatkan temuan bahwa, penerapan pembelajaran kooperatif model STAD dapat meningkatkan hasil belajar IPS siswa kelas VII.2 SMP Negeri 3 Malang. Hal ini dibuktikan pada siklus
1 diperoleh beberapa temuan peneliti yaitu hasil siswa pada siklus 1 meningkat dari data awal sebelum tindakan yaitu pada siklus I sebesar $60 \%$ dan pada siklus 2 meningkat menjadi $80 \%$.

Dalam Penelitian ini peneliti berusaha mengatasi permasalahan dikelas 7.2 SMPN 3 Malang yaitu rendahnya hasil belajar siswa. Dengan melihat karakteristik matari yang begitu komplek sehingga dari hasil kajian peneliti model yang tepat digunakan adalah Students Teams Achievement Division (STAD). Model ini merupakan salah satu tipe pembelajaran yang menekankan adanya kerjasama dalam kelompok.

Dalam pembelajaran model Students Teams Achievement Division (STAD) siswa ditempatkan dalam kelompok belajar beranggotakan empat atau lima orang yang merupakan campuran menurut tingkat kemampuan siswa. Guru menyajikan pelajaran kemudian siswa bekerja di dalam kelompok mereka untuk memastikan bahwa seluruh anggota kelompok telah menguasai materi pelajaran tersebut. Pada setiap akhir siklus siswa diberikan tes yang mana pada saat tes ini mereka tidak dapat saling membantu. Point setiap anggota tim ini selanjutnya dijumlahkan untuk mendapatkan skor kelompok. Tim yang mencapai kriteria tertentu diberikan penghargaan berupa penyampaian nama-nama siswa didepan kelas.

Penekanan yang selalu dilakukan guru kepada anggota kelompok agar memiliki rasa tanggung jawab terhadap keberhasilan kelompoknya untuk memahami materi secara untuh adanya penerapan pembelajaran model STAD dengan pembagian tugas dalam 
kelompok secara bergantian pada setiap siklus membuat siswa selalu sadar dengan tugas dan tanggung jawabnya sebagai anggota kelompok. Hal ini menunjukkan bahwa proses pembelajaran melibatkan seluruh siswa.

Dalam penerapan model ini juga guru menekankan dan memotivasi siswa bahwa keberhasilan individu adalah menentukan keberhasilan kelompok dan sebaliknya. Kelompok yang baik adalah kelompok yang aktif dalam kegiatan belajar kelompok, bekerjasama dengan baik dalam, menguasaai isi materi dan mampu menjawab permasalahan kelompok lain yang belum terpecahkan. Sehingga setiap kelompok berlombalomba menjadi kelompok yang terbaik.

Siswa yang belajar dengan pembelajaran model STAD memiliki rata-rata kemampuan hasil belajar siswa lebih tinggi dari siswa yang belajar dengan metode biasa karena dalam model STAD memungkinkan siswa untuk berinteraksi, bekerja sama dengan anggota kelompoknya lebih sering dan intensif. Untuk mengembangkan kemampuan hasil belajar siswa diperlukan latihan atau pembiasaan yang intensif

Berikut hasil belajar siswa yang diperoleh dari lembar pengamatan selama kegiatan berlangsung, dan selama kegiatan diskusi persentasi serta penilaian dari hasil belajar siswa (Tes)

1. Kegiatan Selama Proses Pembelajaran

Berdasarkan hasil observasi selama proses pembelajaran dan analisa data menunjukan bahwa hasil belajar siswa selama proses pembelajaran pada siklus I dan siklus II melalui penerapan model STAD dapat meningkatkan hasil hasil belajar siswa. Pada siklus I persentase hasil belajar sebesar $63.33 \%$ atau sebanyak 19 orang sedangkan pada siklus II mengalami peningkatan sebesara $80 \%$ atau 24 orang siswa. Beberapa tindakan pada siklus I dan siklus II ternyata berpengaruh positif terhadap hasil belajar siswa yang diamati melalui lembar observasi selama kegiatan belajar mengajar berlangsung dengan penerapan model STAD.

2. Kegiatan Diskusi dan Persentasi Berdasarkan hasil observasi kegiatan diskusi dan persentasi dan analisa data juga menunjukan peningkatan hasil belajar siswa selama kegiatan diskusi dan persentasi. Pada siklus I persentasenya sebesar $86.66 \%$ atau siswa yang memenuhi target KKM sebanyak 26 orang sedangkan pada siklus II mengalami peningkatan sebesar $90 \%$ atau dengan jumlah siswa sebanyak 27 orang.

3. Hasil Belajar

Penilaian hasil belajar siswa dilakukan setiap siklus berakhir berikut persantse hasil belajar siswa sebelum tindakan dan setiap siklusnya. Diketahui sebelum pra tindakan siswa yang memenuhi Kriteria Ketuntasan Minimal sebanyak 18 oranag atau $60 \%$ dan setelah para tindakan siklus I siswa mengalami peningkatan yaitu sebanyak 19 orang atau $63.33 \%$ sedangkan siklus II siswa kembali mengalami peningkatan sebesar 80 $\%$ atau 24 orang siswa.

Berdasarkan penelitian ini dapat disimpulkan bahwa hasil belajar siswa SMPN 3 Malang kelas 7.2 pada materi penduduk Indonesia dan pemanfaatan sumber daya alam pokok bahasan bahasan komposisi penduduk Indonesia 
dapat diupayakan dengan menerapkan model (STAD) Student Team Achievement Division. Model ini sangat efektif diterapakan dalam meningkatkan hasil belajar siswa dengan melihat karakteristik materi yang disampaikan juga sangat kompleks.

\section{KESIMPULAN DAN SARAN}

\section{Kesimpulan}

Berdasarkan paparan data dan hasil pembahasan, maka dapat disimpulkan beberapa hal berikut: Model Pembelajaran Kooperatif dengan (STAD) Student Team Achievement Division dapat meningkatkan hasil belajar siswa kelas 7.2 SMPN 3 mata pelajaran Ilmu Pengetahuan Sosial pada materi Penduduk Indonesia dan Pemanfaatan Sumber Daya Alam Malang. Hal ini jelas terlihat dari nilai ketuntasan belajar siswa pada saat sebelum ada tindakan dan setelah ada tindakan. Pada saat sebelum ada tindakan porsentase siswa hanya $60 \%$ dan pada ssiklus I meningkat menjadi $63.33 \%$ sedangkan pada nilai ketuntasan belajar pada siklus II jauh lebih meningkat lagi menjadi $80 \%$. Dari paparan tersebut jelas menunjukan adanya peningkatan hasil belajar siswa sebelum tindakan dan setelah tindakan dengan menggunakan model pembelajaran (STAD) Student Teams Achievement Division.

\section{Saran}

Berdasarkan hasil penelitian, beberapa saran yang perlu disampaikan agar pelaksanaan pembelajaran lebih baik lagi kedepan berikut saran yang yang dapat dberikan:

1) Bagi guru bidang studi Ilmu

Pengetahuan Sosial

Semoga Penerapan pembelajaran kooperatif model (STAD) Student Teams Achievement Division dapat dijadikan alternative dalam pembelajaran IPS untuk meningkatkan hasil belajar siswa. Tentunya guru bidang studi sudah memperhatikan karakteristik siswa.

2) Bagi peneliti lain

Semoga peneliti ini dapat menjadi acuan berikutnya dapat melakukan penelitian tentang penerapan pembelajaran kooperatif model (STAD) Student Teams Achievement Division dalam pembelajaran Ilmu Pengethuan Sosial dengan materi pelajaran yang lain. Sebelum menggunakan pembelajaran model (STAD) Student Teams Achievement Division perlu memperhatikan karakteristik siswa, karakteristik materi, dan karakteristik kompetensi yang harus dicapai. Agara apa yang ingin di capai dapat berhasil.

\section{DAFTAR RUJUKAN}

Amri Sofan, Ahmadi Iif Khoirul. 2010. Proses Pembelajaran Kreative dan Inovatif dalam Kelas, Jakarta: Prestasi Pustakaarya (halaman 67).

Asrori Mohammad, 2007. Penelitian Tindakan Kelas, Bandung: Wacana Prima.

Daryanto, 2011. Media Pembelajaran, Bandung: PT Sarana Tutorial Nuarani Sejahtera.

Dimyati dan Mudjiono, 2013. Belajar dan Pembelajaran, Jakarta: Rineka Cipta

Ekawarna. 2013. Penelitian Tindakan Kelas. Ciputat : Referensi (GP Press Group).

Isjoni. 2007. Cooperative Learning. Bandung: Alfabeta (halaman 15) 
Kunandar. 2013. Penilaian Autentik: Penilaian Hasil Belajar Peserta Didik Berdasarkan Kurikulum 2013, Jakarta: RajaGrafindo Persada.

Mulyasa H.E, 2013. Pengembangan Implementasi Kurikulum 2013, Bandung: Remaja Rosdakarya.

Munawar Indra, 2013. Pengertian Hasil Belajar. (http:// Indra Munawar I'M.blogspot.com, diakses 12 Desember 2013)

Oemar Hamalik, 2006. Proses Belajar Mengajar, Bandung: Bumi

Aksara

Pusat Pembinaan dan Pengembangan Bahasa, 2009. Pedoman Umum Ejaan Bahasa Indonesia Yang Disempurnakan. Jakarta: Departemen Pendidikan Nasional Republik Indoensai

Rasyid Harun, Mansur, 2007. Penilaian Hasil Belajar, Bandung: CV Wacana Prima.

Sugiyono. 2010. Metode Penelitian Pendidikan: Pendekatan Kuantitatif Kualitatif, dan R.D. Bandung: Alfabeta, CV.

Sumarmi, 2012. Model - Model Pembelajaran Geografi. Yogyakarta: Aditya Media Publishing.

Suprapto, 2013. Metodologi Penelitian: Ilmu Pendidikan dan Ilmu - Ilmu Pengetahuan Sosial: Penelitian kuantitatif dan Kualitatif Dilengkapi dengan Teknik Pengolahan Data dan Tabel Statistik, Yogyakarta: Center For Academic Publising Servic.
Trianto. 2007. Model - model Pembelajaran Inovatife Berorientasi Konstruktivistik. Jakarta: Prestasi Pustaka 